\title{
Structural Characteristics and Evolution Process of the Metamorphic Buried Hill: A Case of BZ Oilfield in Bohai Bay, China
}

\author{
Hua Zheng, Xuwei Bie, Xinfei Song, Yong Jiang, Wenchao Liu \\ Tianjin Branch of CNOOC Limited, Tianjin, China \\ Email: zhenghua@cnooc.com.cn
}

How to cite this paper: Zheng, H., Bie, X.W., Song, X.F., Jiang, Y. and Liu, W.C. (2022) Structural Characteristics and Evolution Process of the Metamorphic Buried Hill: A Case of BZ Oilfield in Bohai Bay, China. International Journal of Geosciences, 13, 1-11.

https://doi.org/10.4236/ijg.2022.131001

Received: November 16, 2021

Accepted: January 7, 2022

Published: January 10, 2022

Copyright $\odot 2022$ by author(s) and Scientific Research Publishing Inc. This work is licensed under the Creative Commons Attribution International License (CC BY 4.0).

http://creativecommons.org/licenses/by/4.0/

\section{(c) (i) Open Access}

\begin{abstract}
Bozhong oilfield which is abbreviated as BZ oilfield is the first oilfield with deep metamorphic buried hill that is discovered reserves of billion-ton in Bohai Bay. Affected by multi-stage tectonic movements, the distribution of fractures is very complex in this area, therefore it is significant to study the evolution of structures for understanding the distribution of fractures. In view of the complexity on the tectonic evolution of the buried hill region in the study area, the influence of tectonic movements on the formation of fractured reservoir is analyzed, and the research results lay the foundation for the efficient development in this type of the oilfield. The results show that main faults, which is formed during early Indosinian and Yanshanian period, are mainly developed in the BZ oilfield area, and the fracture strike has mainly east-west and north-east-east trend. Based on the analysis of the relationship among tectonic evolution, regional stress field and fracture development, it is considered that Indosinian extrusion is the main reason for the formation of main direction faults in the study area. Yanshanian strike-slip transformation and Himalayan reactivation further controlled the development of the fractured reservoirs in the later stage, and formed the present fracture network system. Well block 5 is located in passive plate system during Indosinian period, it is affected by Himalayan stretching and long-term activation of large faults in the later stage, so that the effective fractures are relatively developed. The result plays an important role in guiding the overall plan deployment of the BZ oilfield.
\end{abstract}

\section{Keywords}

Bohai Bay, BZ Oilfield, Metamorphic Rock, Buried Hill, Tectonic Evolution, Stress 


\section{Introduction}

$\mathrm{BZ}$ oilfield is the first deep metamorphic buried hill oilfield which is discovered reserves of billion-ton in the Bohai Bay. The main area is buried-hill reservoir covered by Mesozoic strata, which has weak weathering and leaching, low net to gross ratio and great difference in reservoir development in different locations. Its genesis and distribution law are different from metamorphic buried-hill reservoirs in other areas [1] [2] [3] [4] [5]. Affected by the multi-phase tectonic movements, the distribution of fractures is very complex in various parts of the oilfield block. Therefore, it is important to study the tectonic evolution history in depth to understand the fracture distribution law. In view of the discovery of BZ oilfield, the structural features and drilling data of the study area were used to study the structural evolution characteristics of the target region, and analyze the influence of tectonic movement on the distribution of fractures, so as to provide the corresponding theoretical basis for guiding the efficient development of this type of oil field (Figure 1).

\section{Regional Geological Background}

BZ oilfield is located in the southwestern part of the Bozhong sag (Figure 2), adjacent to the Shaleitian swell in the north, main-Bozhong sag in the east and sub-sag in the west. It is a complex oilfield with fault block formed by the mutual cutting control of the slip-extension fracture system. Well block 5 is located in the core region of semi-backlash structure, and well BZ-5 is the high point of the structure with depth of $4200 \mathrm{~m}$. The strata are the Fourth Series Plain Group, the Neoproterozoic Minghuazhen and Tantao Groups, the Paleoproterozoic Dongying and Shahejie Groups, the Mesozoic and Neoproterozoic buried-hill from top to bottom, and the main target layer is located in the Neoproterozoic buried-hill. In the southwest part of the oilfield, there is no Mesozoic overlying area. It is a Neoarchean buried-hill covered by Cenozoic, which is composed of

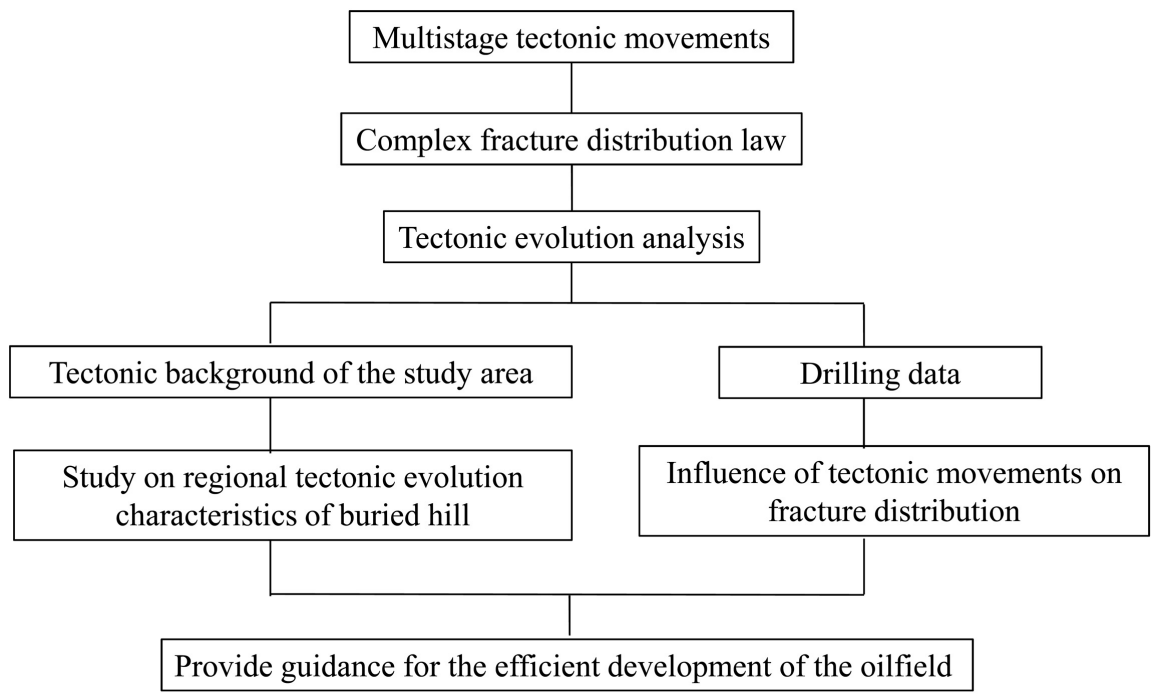

Figure 1. Flow chart of structural evolution analysis. 


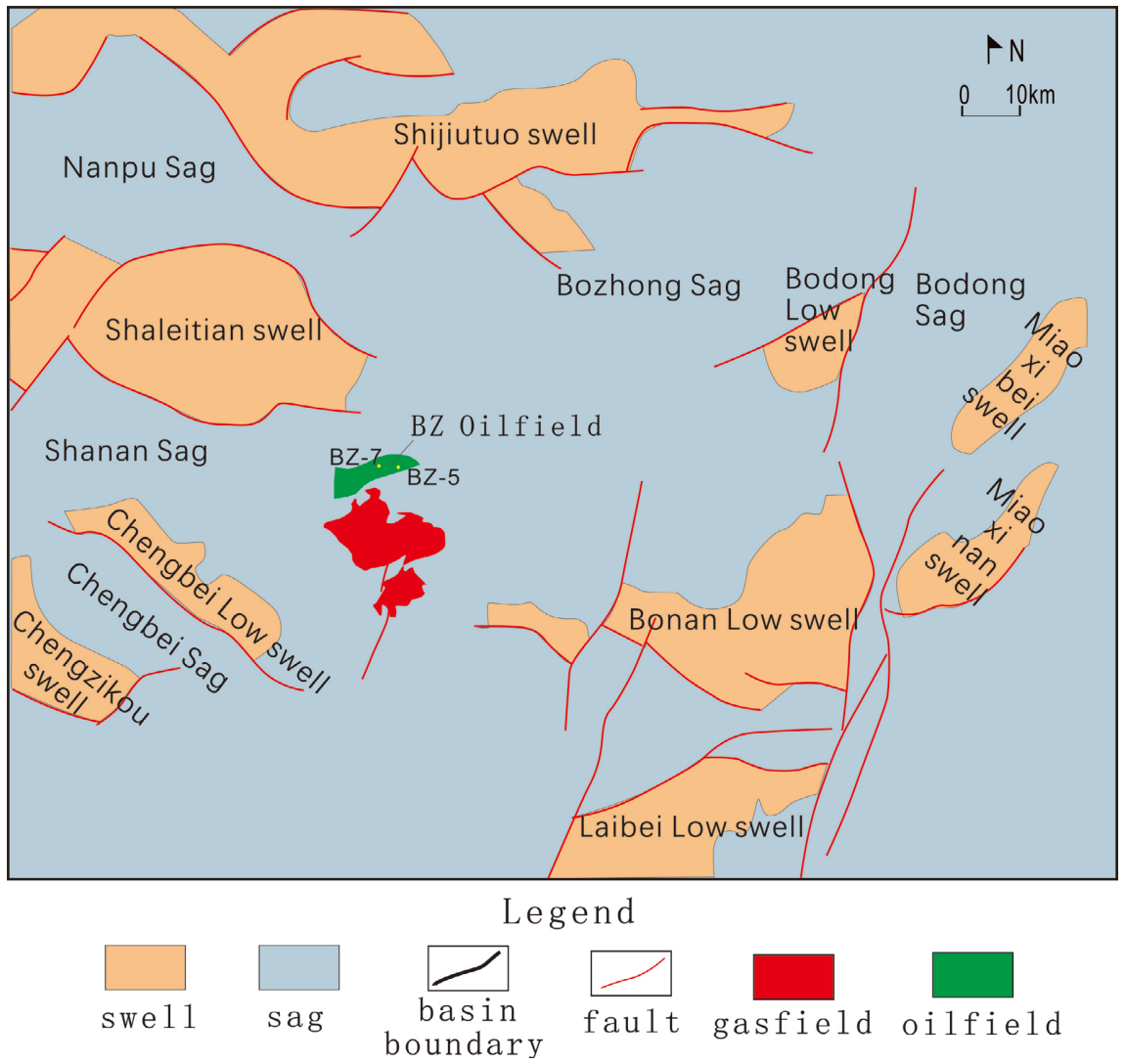

Figure 2. Regional structure location of the BZ oilfield.

NeoArchean granite gneiss and top conglomerate, with average porosity of $3.6 \%$ and average permeability of $5.9 \mathrm{mD}$. The eastern well block 5 and 7 are NeoArchaean buried-hills under the Mesozoic overburden area, whose buried depth of the reservoir is $4200 \mathrm{~m}$ to $5100 \mathrm{~m}$, and the lithology is mainly metamorphic rocks. The average porosity is $3.1 \%$, and the average permeability is $18.9 \mathrm{mD}$. The reservoir is a highly volatile reservoir with characteristics such as low viscosity of formation crude oil $(0.27 \mathrm{mPa} \cdot \mathrm{s})$ and high dissolved gas-oil ratio $\left(510 \mathrm{~m}^{3} / \mathrm{m}^{3}\right)$.

\section{Petrological Characteristics}

Drilling data has revealed that the thickness of Mesozoic buried-hill stratum in $\mathrm{BZ}$ oilfield is 256.0 - $663.0 \mathrm{~m}$. The Mesozoic buried-hill stratumdirectly overlies the Neo-Archean buried-hill and presents an angular unconformity contact. There are Tuffaceous mudstone, tuff and tuffaceous fine sandstone developed in the upper part of the stratum, and thick conglomerate interbedded with the thin carbonaceous mudstone and coal seam developed in the lower part. According to the observation of drilled cores, wall cores and cuttings, the lithology of Neoarchean buried hill is dominated by metamorphic rocks. Metamorphic rocks mainly comprise regional metamorphic rocks, dynamic metamorphic rocks and mixed rocks [6]. Regional metamorphic rocks mainly develop gneisses (Figure 3); dynamic metamorphic rocks mainly develop cataclastic gneisses and cataclastic 

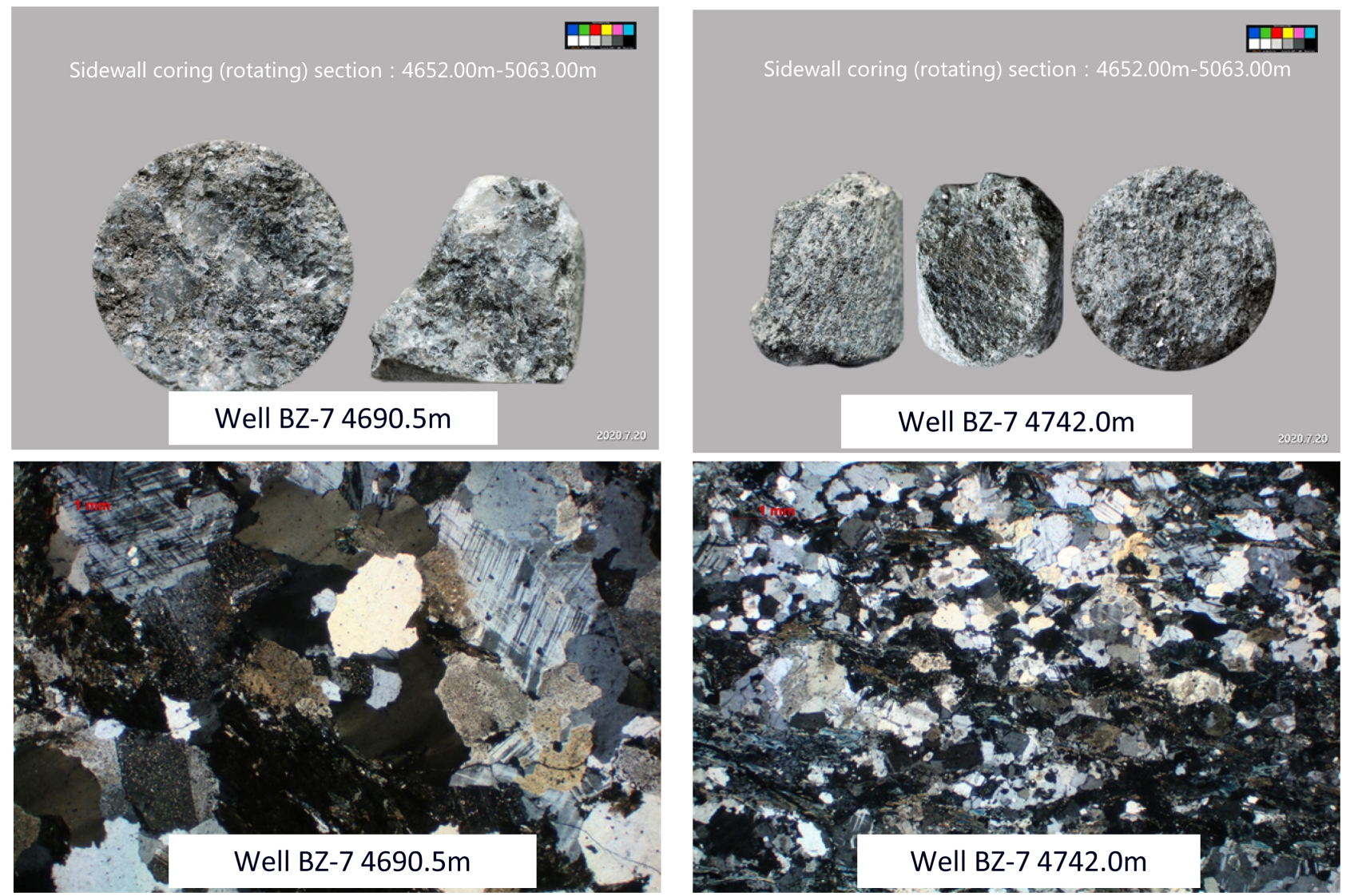

Figure 3. Photographs and photomicrograph of the wall cores and core slices of the gneiss rocks in BZ oilfield.

rocks; mixed rocks mainly develop mixed gneisses and mixed granites; regional metamorphic rock-gneisses dominate the buried-hill of The Neoarchean. The main rock-forming minerals are light-colored quartz, plagioclase and potash feldspar, and the percentage of feldspar and quartz ranges from $20.0 \%$ to $100.0 \%$, with an average of $91 \%$. The content of dark minerals is mainly distributed in the range of $5 \%$ to $15 \%$, with an average of $9 \%$, and the content is relatively low, mainly biotite, muscovite, amphibole, a small amount of siderite, pyrite, ankerite and so on.

\section{Fault System Characteristics}

BZ oilfield is divided into two areas: Mesozoic covered area and no Mesozoic covered area. The southwest area belongs to no Mesozoic covered area, which is the Neoarchean buried hill covered by Cenozoic, it is composed of Neoarchean granite gneiss and glutenite; the eastern area is the Neoarchean buried hill under the Mesozoic coverage area, and the lithology is mainly metamorphic granite.

There are three main types of faults in BZ oilfield area (Figure 4). Type I fault is long-term active fault, with mainly strike NEE and EW, and it controls the development scale of the buried-hill structural framework and trap, with long plane extension. Type II fault is the early active fault, which mainly cuts the 


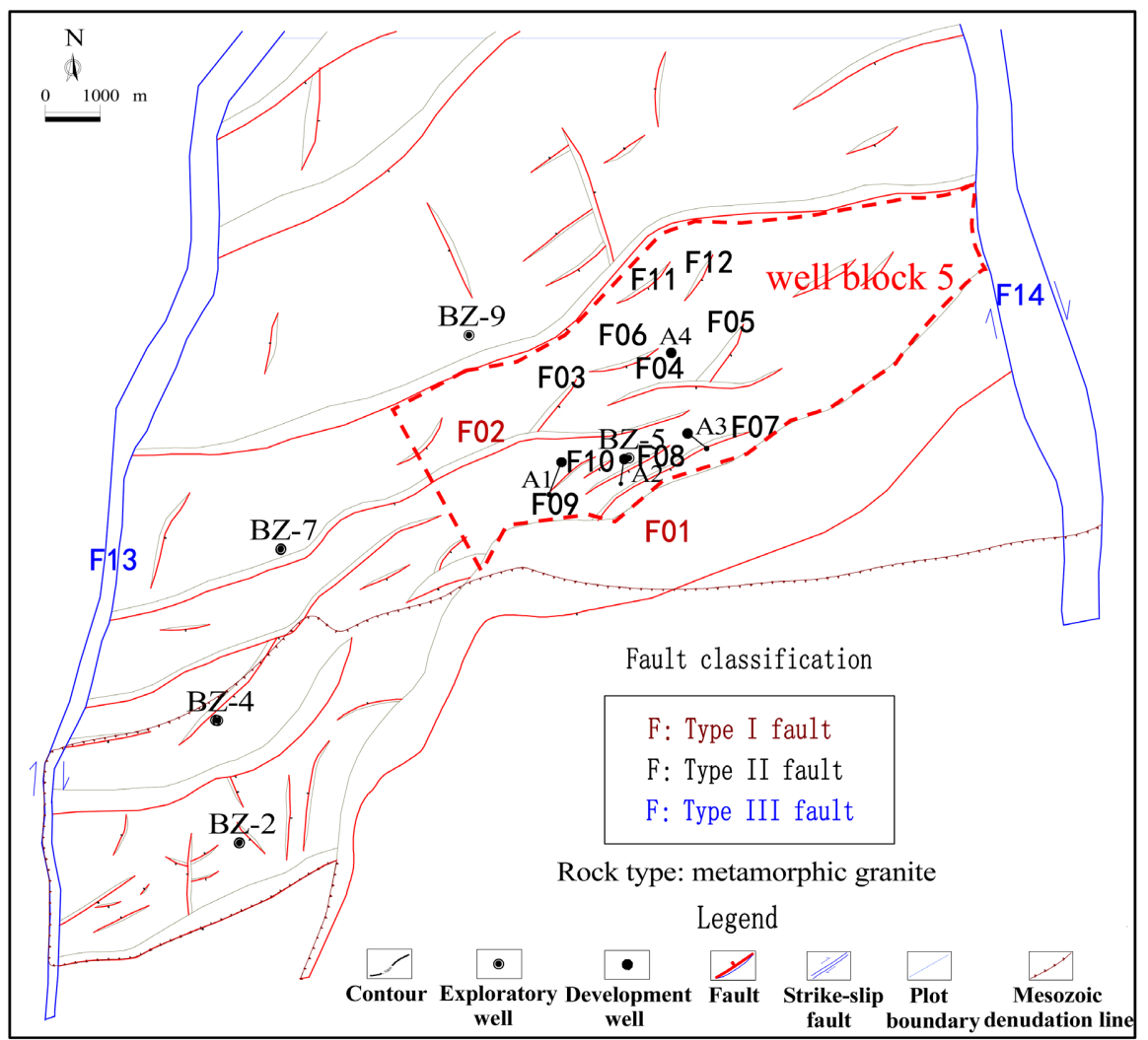

Figure 4. General sketch of the fracture systems on the top surface of the buried hill at the Neoarchean in BZ oilfield.

strata of Archaean, Mesozoic and the lower member of second member in Dongying Formation. Type II fault is inactive in the later stage, and has no obvious control on the trap and structure, but obvious effect on the analysis of buried-hill reservoir. Type III fault is strike-slip fault which plays the role of zoning with long active time and long plane extension, and the orientation is mainly near NS. Taking well block 5 in the main area as an example, there are 13 faults (F1 - F12, F14) in the well block, F1 is a long-term active fault, F2 - F12 are early active faults, and F14 is a strike slip fault. The three types of faults play an important role in zoning the well area.

\section{Tectonic Evolutions of the BZ Oilfield}

\subsection{The External Influence of Tectonic Evolution on Formation of Fractured Reservoir}

The North China Craton, which is in the southwest of Bohai Sea, is located at the intersection of paleo-Asian Ocean, Tethyan Ocean and Pacific tectonic system tracts [7] [8]. Since the end of proterozoic, the tectonic movements of different periods, different directions and different properties have undergone the superposition evolution process, resulting in the superposition of the fault systems with different periods, different properties and different strikes, and finally formed the complex crisscross faults. It is proved that the buried-hill of this area 
mainly experienced Indosinian, Yanshanian, Himalayan (referred to as Himalayan) tectonic movements [9]. Based on the analysis of tectonic evolutions, the buried-hill area has gone through five tectonic stages: 1-pre-Indosinian smooth distribution, 2-Indosinian and early Yanshanian compressive thrusting, 3-middle Yanshanian extensional inversion, 4-late Yanshanian compressive differential uplift, and 5-Himalayan buried stereotype [8] [10]-[15]. It is worth to note that the multistage tectonic movements play an important role in controlling the fracture systems of the buried-hill area.

During the pre-Indosinian period, the Bohai Bay Basin developed stable Paleozoic and Archaean strata, regional absence of part of the intermediate strata during the period. In the Caledonian movement at the end of Middle Ordovician, the stratum uplift was denuded, therefore the Caledonian erosion surface was formed, resulting in the absence of late Ordovician-Silurian-Devonian-Early Carboniferous strata. During the pre-Indosinian period, this area was rose to land, suffering from the long-term weathering denudation and atmospheric fresh water leaching, and formed the early weathering fractures.

During the early Indosinian period, the fractures were formed in this whole area because of the NS compression and nearly EW fractures occurred, which was the main forming period of fractures. In the late Indosinian period, due to the NS squeeze, NNW thrust fractures were produced in the buried-hill area. Extruding fractures were mainly presented. After severe denudation in the later period, the Paleozoic strata located on the hanging wall of the thrust fault were completely denuded, and the Paleozoic strata located on the footwall were partially denuded. The whole Paleozoic strata performed a NW Palaeozoic structure ridge. In the early Yanshan period, differential block uplift was formed due to the EW compression with small scale.

In the middle Yanshan period, the stress of buried-hill area transformed from the compressive stress to the tensile stress, and the NS tension was the strongest. The extensibility of original faults was nearly EW, and then the formation was received deposition, resulting in obvious negative inversion characteristics. Because of the tensile inversion transformation, the early reverse faults became normal faults. The $\mathrm{BZ}$ oilfield which was located in the northern section of the early NW thrust fault had a stronger inversion effect than it in the southern. Thick Mesozoic strata were deposited in the BZ tectonic area in the northern. While, the southern tectonic area had a weaker inversion effect, it was missed the Mesozoic sediments. Suffering from denudation in the later period, the whole area was filled and leveled up. At the same time, due to the influence of the strike-slip effect, the strata near the main strike-slip fault belt compressed, extended and sheared repeatedly over time. Therefore, the faults reconstructed, cut and superimposed each other, resulting in a large number of fracture belts around the strike-slip fault.

In the late Yanshan period, the buried-hill area shifted to a weak compressive stress through a nearly NS trend. The tectonic area was further squeezed and uplifted differently. The tectonic structure was basically high in the north and low 
in the south.

During the Himalayan period, the buried-hill area was mainly in the north and south to tensile stage, while was being subjected to the combined effect of go-slip action. Some faults were controlled to begin inherited activity, which caused stretching activation of the early fractures, produced new tense positive faults, and they were accompanied by a series of tense fractures along the fault strike in the area. Due to the late formation period, these fractures continued to open, which is conducive to the evacuation and preservation of oil and gas.

After the above five stages, the pattern, which had the archean exposed buried-hill in the southwest and the overlying buried-hill in the northeast, were basically formed. Then the whole area received the Paleogene stratigraphic depositions, and the buried-hill was quickly covered and buried by the overlying sediments. As a result, the current low buried-hill structural belt was formed (Figure 5).

In conclusion, controlled by the Indosinian, Yanshanian and Himalayan tectonic movements, main control faults are mainly developed in the buried-hill

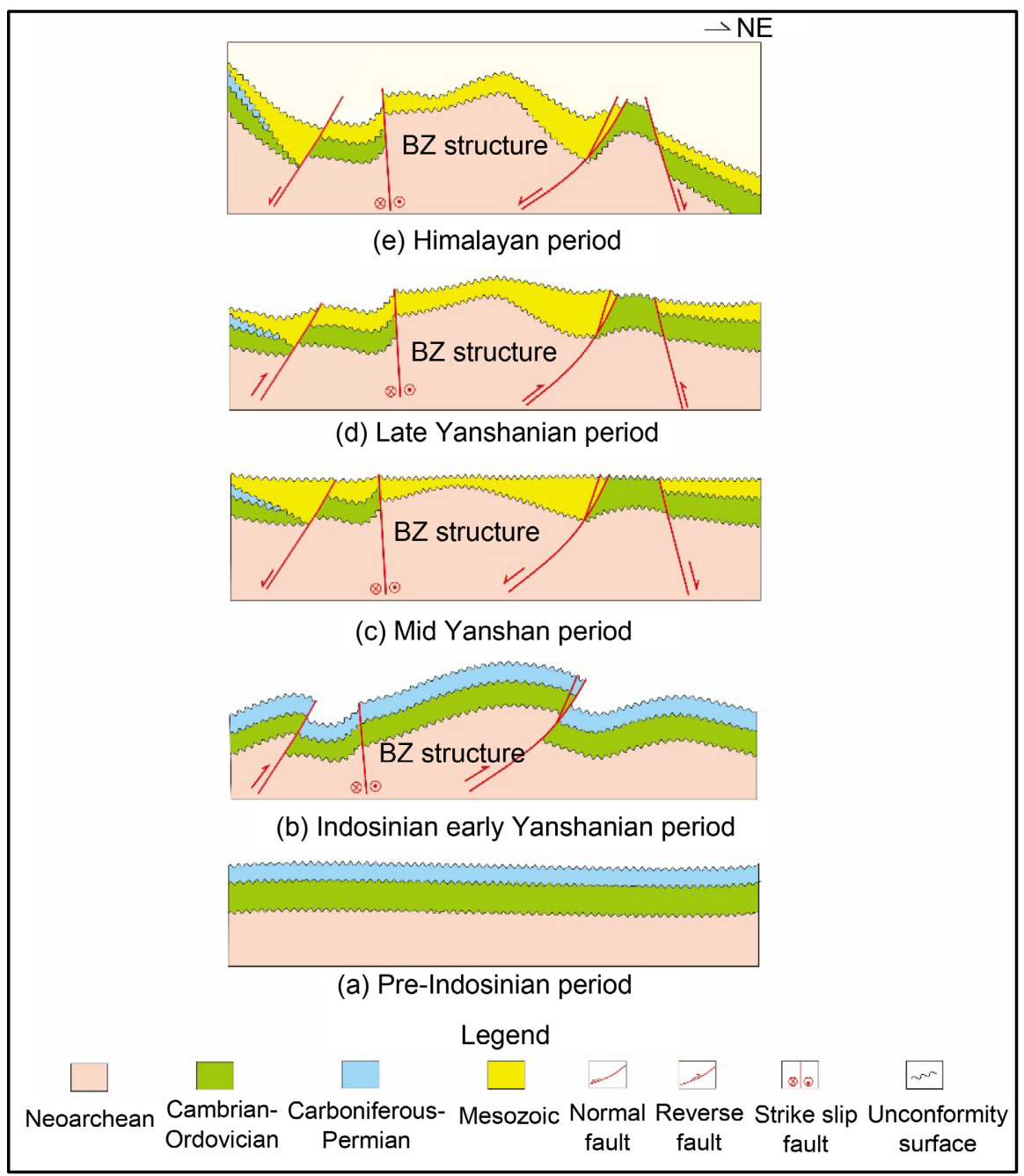

Figure 5. Structural evolution model of the buried hill area. 
area during early Indosinian and Yanshanian period. The fracture trends are basically near EW and NEE, and the whole structure is in the form of broken nose, among which the core of the structure in well block 5 is particularly strongly modified. Combined with the analysis of relationship among the tectonic evolution, regional stress field and fracture development, it is concluded that the Indosinian compression fracture is the main reason for the formation of near EW and NEE faults in the buried-hill area. After that, Yanshanian strike-slip transformation and Himalayan reactivation further controlled the development of fractured reservoirs in the later stage, and formed the present fracture network systems (Figure 6).

Based on the analysis of the tectonic evolution and regional tectonic stress, well block 5 is located in the Indosinian passive disk system, and the effective fractures are relatively developed in the late stage under the influence of the Himalayan stretching and long-term activation of large faults. The statistical results of fracture density and distance from fault show that effective fracture density decreases as the distance from the fault becomes farther (Figure 7). Production

Construction period Tectonic stress Fault Construction style

Figure 6. Analysis diagram of tectonic stress field and fracture formation during the different tectonic stages.

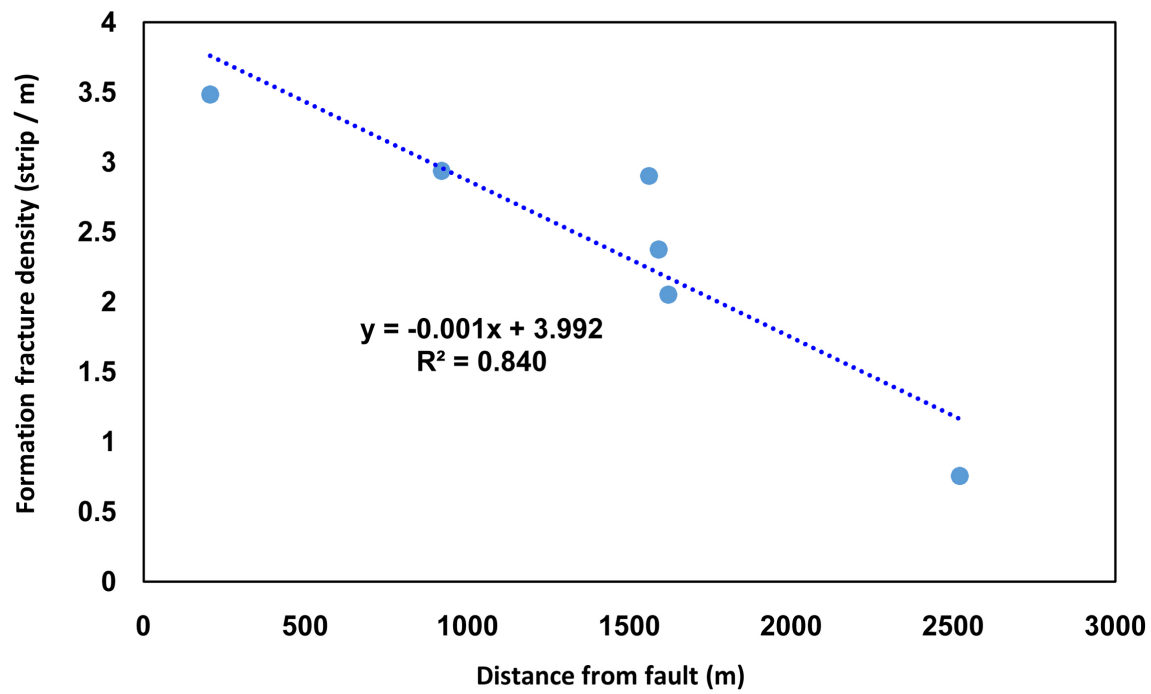

Figure 7. Relationship between the density of fractures and distance from the fault, BZ oilfield. 
practice further confirmed that three wells near the large fault produced an average of 200 tons of oil and 110,000 cubic meters of gas per day from the BZ oilfield, with more effective fractures, and one well far from the large fault produced 30 tons of oil and 40,000 cubic meters of gas per day, with less effective fractures. Its cognition can further guide the overall regional development in the later stage, laying a solid foundation for developing oilfield more efficiently.

\subsection{The Internal Influence of Tectonic Evolution on the Formation of the Fractured Reservoir}

Affected by multi-stage tectonic movement, rock fragmentation has led to changes in rock properties. In the granite gneiss and its cataclastic rocks of the BZ oilfield, the total amount of quartz and feldspar is up to more than $80 \%$. Due to its brittle nature and ancient age, it has experienced multi-stage tectonic movements, which are easy to produce a large number of fractures and form good reservoirs. In addition, plagioclase is easy to be dissolved, which also provides more dissolution pores for reservoir development, and the brittleness of rock tends to be greatly enhanced due to the lower temperature and pressure near the paleo-weathering surface. When the pressure exceeds a certain limit, the granite gneiss rocks will be broken and fractured. However, large-scale fissures are developed in the deeper part below the weathered surface under the influence of the ancient faults in the buried-hill area. Therefore, the nature property of rocks is the inherent fundamental factor affecting the development of reservoir space [16] [17] [18].

The granite gneiss rocks in the main part of the BZ oilfield (well area 5 and 7) have low dark mineral content, their lithological cohesion to elastic modulus ratio is small, and their high brittleness index makes them prone to fracture development under geological stress, which further constitute the internal causes of fractures in the Archaean period (Figure 8).

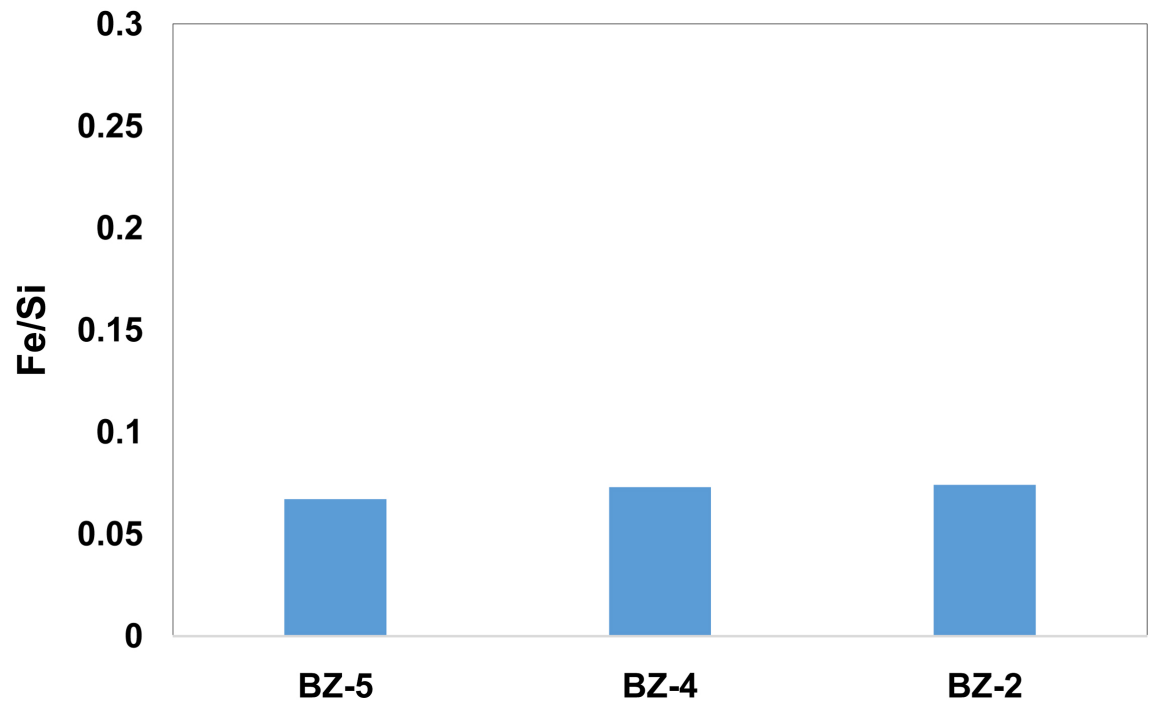

Figure 8. Comparison of dark minerals in BZ oilfield. 


\section{Conclusions}

1) The buried-hill area is controlled by multi-stage tectonic movements, and the main faults which are formed during the early Indosinian and Yanshanian period are mainly developed. The fracture trends are basically near EW and NEE, and the whole structure is in the form of broken nose, among which the core of the structure is particularly strongly modified in well block 5 .

2) Based on the analysis of tectonic evolution, the regional stress and fracture development, the Indosinian compression fracture is the main reason for the formation of EW-trending and NEE-trending faults in the buried-hillarea. Yanshanian strike-slip transformation and Himalayan reactivation further controlled the development of fractured reservoirs in the later stage, and formed the present fracture network systems, which are the external causes of the fracture formation. Meanwhile, low dark mineral and brittle quality are the internal cause of the fracture formation.

3) The development degree of buried-hill reservoir is mainly affected by tectonic activities. The area which is near the fault with long-term activity belongs to the area of dominant reservoir. The production practice has proved that the fractures are more effective near the large faults. The result plays an important role in guiding the overall plan deployment of the $\mathrm{BZ}$ oilfield.

\section{Conflicts of Interest}

The authors declare no conflicts of interest regarding the publication of this paper.

\section{References}

[1] Xu, C.G., Yu, H.B., Wang, J., et al. (2019) Formation Conditions and Accumulation Characteristics of Bozhong 19-6 Large Condensate Gas Field in Offshore Bohai Bay Basin. Petroleum Exploration and Development, 46, 25-38. https://doi.org/10.1016/S1876-3804(19)30003-5

[2] Hou, M.C., Cao, H.Y., Li, H.Y., et al. (2019) Characteristics and Controlling Factors of Deep Buried-Hill Reservoirs in the BZ19-6 Structural Belt, Bohai Sea Area. Natural Gas Industry, 39, 33-44. https://doi.org/10.1016/j.ngib.2019.01.011

[3] Tong, K.J., Zhao, C.M., Lv, Z.B., et al. (2012) Reservoir Evaluation and Fracture Characterization of the Metamorphic Buried Hill Reservoir in Bohai Bay. Petroleum Exploration and Development, 39, 56-63. https://doi.org/10.1016/S1876-3804(12)60015-9

[4] Zhou, X.H., Xiang, H., Yu, S., et al. (2005) Reservoir Characteristics and Development Controlling Factors of JZS Neo-Archean Metamorphic Buried Hill Oil Pool in Bohai Sea. Petroleum Exploration and Development, 32, 17-20.

[5] Xu, C.G., Du, X.F., Liu, X.J., et al. (2020) Formation Mechanism of High-Quality Deep Buried-Hill Reservoir of Archaean Metamorphic Rocks and Its Significance in Petroleum Exploration in Bohai Sea Area. Oil \& Gas Geology, 41, 235-247+294.

[6] Jia, H.S. (2019) Reservoir Characteristics of Metamorphic Buried Hill in BZ Gas Field. Petroleum Geology and Engineering, 33, 1-4.

[7] Xiao, S.G., Lv, D.Y., Hou, M.C., et al. (2019) Mesozoic Tectonic Evolution and Bu- 
ried Hill Formation Mechanism in the Southwestern Bohai Sea. Natural Gas Industry, 39, 34-44.

[8] Li, S.Z., Suo, Y.H., Dai, L.M., et al. (2010) Development of the Bohai Bay Basin and Destruction of the North China Craton. Earth Science Frontiers, 17, 64-89.

[9] Niu, C.M., Wang, X., Ye, T., et al. (2018) Characteristics and Prediction of Fractures in Large-Scale Metamorphic Buried Hills in Southwestern Bozhong Sag. Oil Drilling \& Production Technology, 40, 66-69.

[10] Li, H.G., Du, X.D., Lu, K.Z., et al. (1999) Evolution and Structural Characteristics of the Mesozoic Era in the Central-West Part of Bohai Bay Area. Journal of the University of Petroleum, China, 23, 1-5.

[11] Hou, T.G., Qiang, X.L. and Cai, D.S. (2001) The Tectonic Evolution of Bohai Basin in Mesozoic and Cenozoic Time. Acta Scientiarum Naturalium Universitatis Pekinensis, 37, 845-851.

[12] Yu, F.S., Qi, J.F. and Wang, C.Y. (2002) Tectonic Deformation of Indosinian Period in Eastern Part of North China. Journal of China University of Mining \& Technology, 31, 402-406.

[13] Zhao, Y., Xu, G., Zhang, S.H., et al. (2004) Yanshanian Movement and Conversion of Tectonic Regimes in East Asia. Earth Science Frontiers, 11, 319-328.

[14] Zhou, L.H., Li, S.Z., Liu, J.Z., et al. (2003) The Yanshanian Structural Style and Basin Prototypes of the Mesozoic Bohai Bay Basin. Progress in Geophysics, 18, 692-699.

[15] Xue, Y.A. and Wang, D.Y. (2020) Formation Conditions and Exploration Direction of Large Natural Gas Reservoirs in the Oil-Prone Bohai Bay Basin, East China. Petroleum Exploration and Development, 40, 260-271. https://doi.org/10.1016/S1876-3804(20)60046-5

[16] Yuan, J. (2004) Characters and Influence Factors on Archeozoic Reservoir in the Chengbei 30 Buried Hills. Acta Petrolei Sinica, 25, 48-51+F003.

[17] Ge, Z.D., Wang, X.Z., Zhu, M., et al. (2011) Reservoir Characteristics of Archean Magmatic Rocks in Dongying Sag. Lithologic Reservoirs, 23, 48-52.

[18] Zhang, P., Hu, M., He, B., et al. (2011) Analysis on Main Controlling Factors of Archaeozoic Base Rock Reservoir in Dongying Depression. Fault-Block Oil \& Gas Field, 18, 18-21. 